\title{
Pengaruh Kepemilikan Institusional, Jumlah Komite Audit dan Komisaris Independen terhadap Total Kompensasi
}

\author{
Jenny Winda Wati dan RR Kartika Nuringsih \\ Program Studi Manajemen Fakultas Ekonomi dan bisnis \\ Universitas Tarumanagara \\ Email: Jennywindawati4@gmail.com
}

\begin{abstract}
The research aims to examine the Institutional Ownership, influence of the size of audit committees, and Independent Commissioner on corporate performance of a company and impact on Executive Compensation. This study uses purposive sampling method. The research sample is 77 of manufacturing companies listed on the Indonesian Stock Exchange from 2016 to 2018. The data used are secondary data based on Smart PLS 3.2.8. The results showed that the Institutional Ownership and Independent Commissioner have a effect on company performance. However, size of audit committeeshave a no effect on performance of the company. Furthermore, company performance have a effect on executive compensation.
\end{abstract}

Keywords: Audit committee; Corporate performance; Institutional ownership; Independent Commissioner; Executive compensation.

Abstrak: Penelitian ini bertujuan untuk menganalisis kepemilikan institusional, ukuran komite audit, dan komisaris independen terhadap kinerja perusahaan dan berdampak pada kompensasi eksekutif. Studi ini menggunakan metode purposive sampling. Sampel penelitian ini adalah 77 perusahaan manufaktur yang terdaftar di Bursa Efek Indonesia dari 2016 sampai 2018. Data yang digunakan adalah data sekunder berdasarkan Smart PLS versi 3.2.8. Hasil penelitian menunjukkan bahwa kepemilikan institusional dan komisaris independen memiliki dampak terhadap kinerja perusahaan. Namun, ukuran komite audit tidak berpengaruh pada kinerja perusahaan. Selain itu, kinerja perusahaan berpengaruh terhadap kompensasi eksekutif.

Kata Kunci: Komite Audit; Komisaris Independen; Kinerja Perusahaan; Kepemilikan Institusional; Kompensasi Excecutive

\section{LATAR BELAKANG}

Perekonomian Indonesia yang sedang melemah dikarenakan perekonomian global yang sedang goyah, membuat beberapa perusahaan mengalami banyak kendala. Perusahaan sendiri mempunyai tujuan yang harus dicapai. Salah satu tujuan yang mendirikan perusahaan adalah untuk memaksimalkan nilai perusahaan (Salvatore 2005). Oleh karena itu, manager atau agen perusahaan memiliki tugas dan tanggung jawab untuk memaksimalkan kekayaan pemegang saham dengan menunjukkan kinerja perusahaan yang baik sehingga akan meningkatkan nilai perusahaan (Suharli, 2006). Cara yang efektif dalam mencapai tujuan perusahaan adalah dengan menciptakan keuntungan perusahaan yang cenderung naik dan stabil. Namun, hal ini tentunya harus didukung dengan pengelolaan keuangan yang baik. Kinerja eksekutif atau CEO perusahaan diapresiasi salah satunya dalam bentuk gaji dimana dari gaji tersebut akan mencerminkan pendapatan yang diterima oleh eksekutif tersebut.

Namun dalam pelaksanannya hubungan antara agen dengan prinsipal sering terjadi perbedaan perpektif, sehingga menimbulkan konflik kepentingan. Menurut teori keagenan konflik yang terjadi antara pemegang saham dengan agen disebut dengan agency conflict. Menurut Jensen \& Meckling (1976) mengungkapkan masalah agensi ini muncul karena 
seorang (agen) berperilaku seolah-olah sedang memaksimalkan kesejahteraan (prinsipal). Tapi kenyataannya agen memiliki tujuan tertentu yang berbeda dari yang diinginkan prinsipal (pemilik modal) sehingga terjadilah konflik kepentingan antara agen dan principal. Dengan demikian melalui mekanisme gaji yang diterima oleh agen diharapkan dapat menekan potensi konflik yang terjadi dalam perusahaan.

Teori agensi mendorong munculnya Good Corporate Governance dalam pengelolaan bisnis perusahaan, dimana Good Corporate Governance diharapkan dapat meminimalkan hal-hal melalui pengawasan terhadap kinerja para agen (Hamdani, 2016).Tolakukurgood corporate governancesebagai alat adalah kepemilikan institusional yang penting dalam mekanisme tata kelola perusahan. Menurut Hidayah, et al. (2019) peranan kepemilikan institusional seperti perusahaan asuransi, bank, perusahaan investasi, dan lembaga lain akan mendorong tingkat pengawasan yang lebih optimal di Indonesia menjalankan perusahaan. Selanjutnya, sesuaidengan Surat Edaran Otoritas Jasa Keuangan No. 55/POJK.04/2015 bahwa komite audit adalah komite yang dibentuk oleh dan bertanggung jawab kepada dewan komisaris dalam membantu melaksanakan tugas dan fungsi dewan komisaris.

Seperti yang tertuang dalam Surat Edaran Otoritas Jasa Keuangan No.55/POJK.04/2015 komisaris independen adalah anggota Dewan komisaris yang berasal dari luar Emiten atau perusahaan publik dan memenuhi persyaratan sebagaimana dimaksud dalam peraturan Otoritas Jasa Keuangan ini. Dengan penerapan good corporate governance yang baik diharapkan akan mendukung tercipta peningkatkan kinerja perusahaan.Kinerja perusahaan ini merupakan salah satu cara pengukuran prestasi agen (manajer) yang berdampak terhadap kompensasi yang diterima. Terkait dengan penelitian ini maka objek penelitian yang akan digunakan adalah perusahaan di sector manufaktur yang terdaftar dalam Bursa Efek Indonesia tahun 2016-2018.

\section{KAJIAN TEORI}

Agency Theory. Jensen dan Meckling (1976) mengatakan bahwa: "the problem of inducing an "agent" to behave as if he were maximizing the "principal's" welfare is quite general." Artinya masalah agensi ini muncul karena agen yang seolah-olah sedang memaksimumkan kesejahteraan prinsipal. Terkadang sebagian besar manajer mempunyai tujuan tersendiri dan kepentingan yang berbeda dengan tujuan utama perusahaan menyebabkan manajer lebih mengutamakan kepentingan pribadinya daripada kepentingan para pemegang saham. Para pemegang saham mengeluarkan biaya yang digunakan untuk memantau kinerja para manajer agar bertindak sesuai dengan keinginan para pemegang saham.

Kinerja Perusahaan. Kinerja perusahaan (Ipinnaiye,2014) menyatakan bahwa: "Firm performance is important for a number of reasons related to job creation, firm survival, innovation, competitiveness and overall economic performance; motivating a large body of research on its determining factors." Yang artinya kinerja perusahaan adalah sesuatu yang penting karena sejumlah alasan terkait kejadian di lapangan kerja, kelangsungan hidup perusahaan, inovasi, daya saing, dan kinerja ekonomi secara keseluruhan; memotivasi banyak penelitian tentang faktor-faktor penentu. Dan pengertian lainnya yang dikatakan oleh Santos \&Luiz (2012) "Firm performance is a relevant construct in strategic management research and frequently used as a dependent variable." Kinerja perusahaan adalah konstruk yang relevan dalam penelitian manajemen strategis dan sering digunakan sebagai variabel dependen.

Kepemilikan Institusional. Perusahaan yang sudah mulai berkembang dan ingin memperluas usahanya akan mencari pinjaman dana modal yang bisa berasal dari pinjaman 
bank atau melakukan go-public yang bisa dilakukan oleh perusahaan-perusahaan besar yang sudah mengikuti persyaratan untuk melakukan go-public. Menurut Siregar \& Utama (2005) kepemilikan institusional merupakan kepemilikan saham perusahaan oleh institusi keuangan seperti perusahaan asuransi, bank, dana pensiun, dan investment banking. Selain itu menurut Wiranata\& Nugrahanti (2013), kepemilikan saham institusional merupakan kepemilikan yang dimiliki oleh pihak institusi yaitu perusahaan asuransi, bank, perusahaan investasi maupun perusahaan swasta.

Komite Audit. Komponen yang dibutuhkan dalam good corporate governance (GCG) diharapkan dapat mampu meningkatkan kontribusi dalam hal salah satunya adalah komite audit. Menurut Salinan peraturan otoritas jasa keuangan Nomor 55/POJK.04/2015 Tentang Pembentukan dan Pedoman Pelaksaan Kerja Komite Auditmengatakan bahwa Komite Audit adalah komite yang dibentuk oleh dan bertanggung jawab kepada Dewan Komisaris dalam membantu melaksanakan tugas dan fungsi Dewan Komisaris. Menurut IKAI "Tugas pokok dari komite audit pada prinsipnya adalah membantu Dewan Komisaris dalam melakukan fungsi pengawasan."

Komisaris Independen. Banyaknya hambatan dari perusahaan keluarga adalah jumlah pekerja yang ditempatkan pada jabatan-jabatan penting pada perusahaan, yang bisa diketahui bahwa sebagaian hanya memperoleh dari hasil pembagian jabatan yang diberikan dalam perusahaan keluarga namun menurut Suherman, et al. (2015) Komisaris independen adalah dewan komisaris yang berasal dari luar perusahaan dan tidak memiliki hubungan keluarga dengan dewan direksi. Komisaris independen yang ada di perusahaan yang ada harus berasal dari luar agar terdapat pihak yang bersifat netral tanpa adanya dampak dari kekuatan keluarga atau lebih dapat menghasilkan hasil yang lebih dapat dipercaya oleh orang lain dari perusahaan.

Total Kompensasi. Total Kompensasi yang diberikan juga berhubungan dengan tata kelola perusahaan. Prinsip-prinsip yang ada dalam tata kelola perusahaan salah satu yang dibutuhkan adalah transparansi dari pihak agen kepada pemangku kepentingan. Menurut Bijzak, et al. (2015) "One objective of government intervention is increased transparency, and as a result investors (and researchers) now have more detailed information about the level and structure of executive compensation." Yang berarti bahwa salah satu tujuan tindakan yang diambil oleh pemerintah adalah meningkatkan Transparasi dan sebagai sebuah hasil dari investor (penulis) sekarang lebih mendapat informasi yang detai tentang tingkat dan stuktur dari kompensasi eksekutif.Perusahaan yang memberikan jumlah kompensasi kepada para para pekerja dilihat dari seberapa baik kinerja perusahaan. Menurut Suherman, et al. (2015) mengatakan bahwa kompensasi eksekutif diartikan sebagai imbal jasa yang berupa finansial maupun non finansial diberikan oleh pemilik perusahaan kepada para eksekutif atas hasil kinerja maksimal yang telah dilakukan selama menjalankan suatu perusahaan.

Kerangka Pemikiran. Berdasarkan landasan teori sebelumnya yang dikemukakan oleh beberapa peneliti terdahulu yang telah dibahas, dan menjadi patokan dalam penelitian ini, maka peneliti dapat mengambil dua hipotesis yaitu melalui penyimpulan model nkonseptual dengan komite audit sebagai variable independen $\left(\mathrm{X}_{1}\right)$, kepemilikan institusional sebagai variable independen $\left(X_{2}\right)$, sebagai komisaris independen sebagai variable independen $\left(X_{3}\right)$, dan kinerja perusahaan sebagai variable intervening $(Z)$ serta total kompensasi sebagai variable dependen (Y) adalah sebagai berikut: 


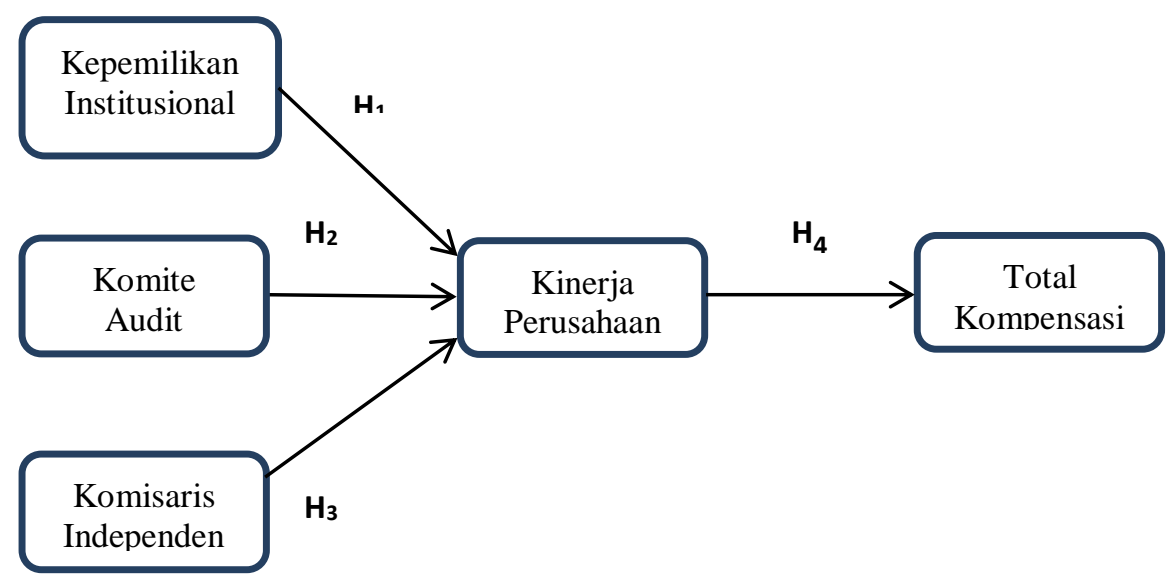

Gambar 1. Kerangka Pemikiran

Dengan mekanisme GCG seperti kepemilikan institusional, komite audit, dan komisaris independen.Diharapkan akan dapat mengurangi biaya agensi dan dapat meningkatkan kinerja perusahaan yang sesuai dengan harapan prinsipal (pemilik modal). Peningkatan kinerja perusahaan akan meningkatkan kompensasi yang diberikan oleh prinsipal berupa gaji, bonus dan tunjangan. Perumusan hipotesis sebagai berikut:

$\mathrm{H}_{1}$ : Kepemilikan institusional dapat digunakan untuk memprediksi kinerja perusahaan secara positif.

$\mathrm{H}_{2}$ : Jumlah komite audit dapat digunakan untuk memprediksi kinerja perusahaan secara positif.

$\mathrm{H}_{3}$ : Komisaris independen dapat digunakan untuk memprediksi kinerja perusahaan secara positif.

$\mathrm{H}_{4}$ : Kinerja perusahaan dapat digunakan untuk memprediksi total kompesasi secara positif.

\section{METODOLOGI}

Tujuan penelitian ini menggunakan berjenis kuantitatif. Desain penelitian yang digunakan adalah deskriptif dengan melibatkan hubungan kausal antara variable bebas meliputi: komite audit, kepemilikan institusional, komisaris independen, kinerja perusahaan (ROA) terhadap variabel terikat total kompensasipada perusahaan yang terdaftar di Bursa Efek Indonesia tahun 2016-2018. Populasi yang digunakan dalam penelitian ini adalah seluruh perusahaan manufaktur yang tercatat di Bursa Efek Indonesia (BEI) tahun 2016-2018.

Teknik pengambilan sampel penelitian dilakukan secaranonprobability samplingkhususnya menggunakan teknik purposive sampling. Metode ini mensyaratkan adanya kriteria khusus dalam memilih sampel yaitu: Perusahaan manufaktur terdaftar di BEI pada tahun 2016-2018, Perusahaan manufaktur delisting di BEI pada tahun 20162018,Laporan keuangan memiliki rugi secara berturut-turut tahun 2016-2018, dan Perusahaan manufaktur tidak memiliki informasi yang lengkap.

\section{HASIL UJI STATISTIK}

\section{Deskripsi Subjek Penelitian}

Jumlah perusahaan manufaktur yang terdaftar di Bursa EfekIndonesia yang menjadi populasi penelitian ini adalah 77 perusahaan manufaktur dimanaperusahaan tersebut 
mengalami beberapa kriteria untuk menentukan jumlah sampel, sehingga jumlah sampe yang digunakan adalah 453 .

\section{Hasil Uji Statistik Deskriptif}

Tabel 1. Uji Statistik Deskriptif

\begin{tabular}{|c|c|c|c|c|c|c|c|c|c|}
\hline Variabel & No. & Missing & Mean & Median & Min & Max & $\begin{array}{c}\text { Standard } \\
\text { Deviation }\end{array}$ & $\begin{array}{c}\text { Excess } \\
\text { Kurtosis }\end{array}$ & Skewness \\
\hline INST & 1 & 0 & 0,672 & 0,700 & 0,000 & 1,000 & 0,225 & 1,023 & $-1,058$ \\
\hline KA & 2 & 0 & 3,091 & 3,000 & 3,000 & 5,000 & 0,355 & 17,588 & 4,182 \\
\hline KI & 3 & 0 & 0,414 & 0,400 & 0,170 & 0,800 & 0,112 & 1,768 & 1,232 \\
\hline TK & 4 & 0 & 23,550 & 24,000 & 20,000 & 28,000 & 1,482 & 0,263 & 0,035 \\
\hline ROA & 5 & 0 & 0,076 & 0,060 & 0,000 & 0,530 & 0,082 & 9,503 & 2,726 \\
\hline
\end{tabular}

Sumber: Hasil pengolahan data panel dengan SmartPLS 3.2.8

Berdasarkan tabel 1,Dari penelitian yang dilakukan selama 3 tahun dengan jumlah perusahaan sebanyak 77 perusahaan diperoleh nilai rata-rata index kepemilikan institusional sebesar 0.672 dengan nilai terendah 0.0000 dan tertinggi 1.0000. Nilai standar deviasi sebesar 0.225 . Pada variabel komite audit penelitian yang dilakukan selama 3 tahun dengan jumlah perusahaan sebanyak 77 perusahaan diperoleh nilai rata-rata index komite audit sebesar 3.091 dengan nilai terendah 3.0000 dan tertinggi 5.0000. Nilai standar deviasi sebesar 0.355. Variabel selanjutnya adalah diperoleh nilai rata-rata index komisaris independen sebesar 0.414 dengan nilai terendah 0.1700 dan tertinggi 0.8000 . Nilai standar deviasi sebesar 0.112 . Selanjutnya variabel kompensasi diperoleh nilai rata-rata index total kompensasi sebesar 23.550 dengan nilai terendah 20.0000 dan tertinggi 28.0000. Nilai standar deviasi sebesar 1.482. Terakhir, pada variabel kinerja perusahaan diperoleh nilai rata-rata index return on assets sebesar 0,076 dengan nilai terendah 0.000 dan tertinggi 0,530. Nilai standar deviasi sebesar 0,082 .

\section{Coefficient of determination (R2)}

Tabel 2. Hasil Coefficient of Determination

\begin{tabular}{|c|c|}
\hline Variabel & R2 \\
\hline ROA & 0,111 \\
\hline Komp & 0,083 \\
\hline
\end{tabular}

Sumber: Hasil pengolahan data panel menggunakan software smartPLS 3.2.8

Berdasarkan tabel 4.2 dapat dilihat bahwa variabel ROA dapat dijelaskan sebesar $11,11 \%$ oleh variabel kepemilikan institusional, komite audit, dan komisaris independen, sedangkan sisanya sebesar $88,89 \%$ dapat dijelaskan oleh variabel-variabel lain di luar variabel penelitian ini. Variabel komp dapat dijelaskan sebesar 8,3\% oleh variabel profitabilitas yaitu ROA, sedangkan sisanya sebesar 91,7\% dapat dijelaskan oleh variabelvariabel lain di luar variabel penelitian ini.

\section{Predictive relevance $\left(\mathrm{Q}^{2}\right)$}

Tabel 3. Hasil predictive relevance

\begin{tabular}{|l|l|}
\hline Variabel & $\mathrm{Q}^{2}$ \\
\hline ROA & 0,083 \\
\hline Komp & 0,079 \\
\hline
\end{tabular}


Sumber: Hasil pengolahan data panel menggunakan software smartPLS3.2.8

Berdasarkan tabel 4.3 dapat dilihat bahwauji predictive relevancemenunjukkan bahwa variabel independen yaitu kepemilikan institusional, komite audit, dan komisaris independen dapat memprediksi variabel intervening dengan baik. Variabel dependen juga dapat diprediksi oleh ROA dan Komp dengan baik. Hasil tersebut didasarkan pada teori yang mengatakan bahwa nilai $\mathrm{Q}^{2}$ harus lebih besar daripada nol (Hair, 2011). Pada hasil penelitian membuktikan bahwa predictive relevance pada ROA memiliki nilai sebesar $0,083\left(\mathrm{Q}^{2}>0\right)$ dan pada Komp sebesar 0,079 $\left(\mathrm{Q}^{2}>0\right)$, sehingga dapat ditarik kesimpulan bahwa konstruk yang digunakan pada penelitian ini dapat mengukur model penelitian dengan baik.

\section{Path coefficients}

Tabel 4. Hasil Bootstrapping

\begin{tabular}{|l|c|c|l|}
\hline Pengaruh & $\begin{array}{l}\text { Path } \\
\text { Coefficient }\end{array}$ & T-statistic & P-values \\
\hline Inst -> ROA & 0,139 & 2,772 & 0,006 \\
\hline KA -> ROA & $-0,029$ & 0,363 & 0,717 \\
\hline KI -> ROA & 0,282 & 3,061 & 0,002 \\
\hline ROA -> Komp & 0,288 & 6,730 & 0,000 \\
\hline
\end{tabular}

Sumber: Hasil pengolahan data panel menggunakan software smartPLS3.2.8

Tabel 5. Hasil Bootstrapping

\begin{tabular}{|l|c|c|c|}
\hline Pengaruh & $\begin{array}{l}\text { Path } \\
\text { Coefficient }\end{array}$ & T-statistic & P-values \\
\hline Inst -> ROA -> Komp & 0,040 & 2,448 & 0,015 \\
\hline KA -> ROA -> Komp & $-0,008$ & 0,358 & 0,721 \\
\hline KI -> ROA -> Komp & 0,081 & 2,653 & 0,008 \\
\hline
\end{tabular}

Sumber: Hasil pengolahan data panel menggunakan software smartPLS3.2.8

Berdasarkan hasil bootstrapping pada Tabel 4.4 dan Tabel 4.5 maka dapat disimpulkan bahwa variabel independen memiliki pengaruh yang positif terhadap variabel intervening dan juga pengaruh yang positif terhadap variabel dependen secara tidak langsung selain variabel komite audit yang menghasilkan pengaruh negative secara langsung dan tidak langsung.Kepemilikan institusional memiliki nilai keterkaitan sebesar 0,139 terhadap ROA dan sebesar 0,040 terhadap Komp perusahaan secara tidak langsung. Komite audit memiliki nilai keterkaitan sebesar -0,029 terhadap ROA dan sebesar -0,008 terhadap Komp secara tidak langsung. Komisaris independen memiliki nilai keterkaitan sebesar 0,282 terhadap ROA dan sebesar 0,081 terhadap Komp secara tidak langsung. ROA sebagai variabel intervening memiliki nilai keterkaitan terhadap variabel dependen, yaitu nilai pasar perusahaan sebesar 0,288. Berikut di bawah ini adalah persamaan dan diagram dari hasil pengujian bootstrapping yang telah dilakukan:

$$
\begin{gathered}
\text { ROA }=\text { 0,139 Inst }-0,029 \text { KA }+0,282 \text { KI } \\
\text { Komp }=0,288 \text { ROA } \\
\text { Komp }=0,040-0,008+0,081
\end{gathered}
$$




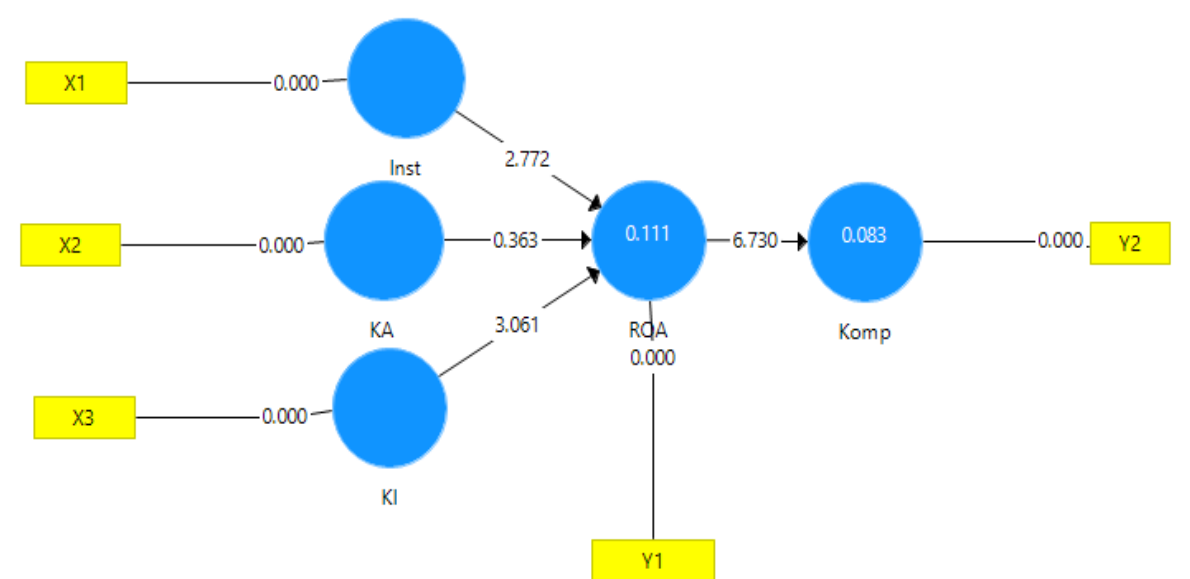

Sumber: Hasil pengolahan data panel menggunakan software smartPLS3.2.8

Gambar 2. Diagram Hasil Bootstrapping

Effect sizes $\left(\mathbf{f}^{2}\right)$

Tabel 6. Hasil Effect Sizes $\left(f^{2}\right)$

\begin{tabular}{|l|l|l|}
\hline Variabel & ROA & Komp \\
\hline Inst & 0,021 & - \\
\hline KA & 0,001 & - \\
\hline KI & 0,084 & - \\
\hline ROA & - & 0,091 \\
\hline
\end{tabular}

Sumber: Hasil pengolahan data panel menggunakan software smartPLS3.2.8

Nilai effect sizes pada penelitian ini yang terdapat pada Tabel 4.7 dapat memberikan kesimpulan bahwa pada variabel Kepemilikan Institusional memiliki efek kecil atau efek perubahan yang tergolong lemah terhadap profitabilitas atau ROA dengan nilai 0,021. Komite audit memiliki efek lemah terhadap profitabilitas atau ROA dengan nilai 0,001. Komisaris independen memiliki efek kecil atau efek perubahan yang tergolong lemah terhadap profitabilitas atau ROA dengan nilai 0,084, sedangkan profitabilitas atau ROA memiliki efek perubahan yang lemah terhadap komp dengan nilai 0,091 .

\section{DISKUSI}

Pengaruh Kepemilikan Institusional terhadap Kinerja Perusahaan (ROA). Berdasarkan pada hasil pengujian terhadap hipotesis pertama, kepemilikan institusional terhadap kinerja perusahaan (ROA) memilikit-statistics sebesar 2,772 (t-statistics $>1,96)$ dan $p$-value sebesar 0,006 ( $p$-value $<0,05$ ). Maka uji penelitian ini membuktikan bahwa kepemilikan institusional memiliki pengaruh positif terhadap kinerja perusahaan (ROA) dan bersifat signifikan. Sehingga $\mathrm{Ha}_{1}$ tidak ditolak. Hal ini berarti kepemilikan institusional akan mempengaruhi kinerja perusahaan. Penelitian Darwis (2009) memperoleh hasil positif dan berpengaruh antara kepemilikan institusional terhadap kinerja, semakin besar kepemilikan institusional maka kinerja perusahaan semakin baik.

Pengaruh Komite Audit terhadap Kinerja Perusahaan (ROA). Berdasarkan pada hasil pengujian terhadap hipotesis kedua, komite audit terhadap kinerja perusahaan (ROA) memiliki $t$-statistics sebesar 0,363 (t-statistics $<1,96$ ) dan $p$-value sebesar 0,717 ( $p$-value $>$ $0,05)$. Maka uji penelitian ini membuktikan bahwa komite audit memiliki pengaruh negatif 
terhadap kinerja perusahaan (ROA) dan bersifat tidak signifikan.Menurut Bansal \& Anil (2016) komite audit tidak dipertimbangkan ketika ada banyak direktur independen di dewan. Semakin sedikitnya jumlah direktur independen di dewan, semakin baik perusahaan mempertahankan kinerja. Jadi hasil yang negative dan tidak signifikan dikarenakan adanya variabel lain seperti komisaris independen yang sudah melakukan tugas dari komite audit, sehingga komite audit tidak diperlukan lagi dalam hal pengawasan.

Pengaruh Komisaris Independen terhadap Kinerja Perusahaan (ROA). Berdasarkan pada hasil pengujian terhadap hipotesis ketiga, kepemilikan institusional terhadap kinerja perusahaan (ROA) memilikit-statistics sebesar 3,061 (t-statistics $>1,96)$ dan $p$-value sebesar 0,002 ( $p$-value $<0,05$ ). Maka uji penelitian ini membuktikan bahwa komisaris independen memiliki pengaruh positif terhadap kinerja perusahaan (ROA) dan bersifat signifikan. Sehingga $\mathrm{Ha}_{3}$ tidak ditolak.Menurut Putra (2015) hal ini dikaitkan dengan fungsi dari komisaris independen yakni melakukan fungsi pengawasan terhadap manajemen, sehingga manajemen akan bertindak sesuai dengan kepentingan pemegang saham.

Pengaruh Kinerja Perusahaan (ROA) terhadap Total Kompensasi. Berdasarkan pada hasil pengujian terhadap hipotesis keempat, kinerja perusahaan (ROA) terhadap total kompensasi memiliki $t$-statistics sebesar 6,730 (t-statistics $>1,96)$ dan $p$-value sebesar 0,000 ( $p$-value $<0,05)$. Maka uji penelitian ini membuktikan bahwa kinerja perusahaan (ROA) memiliki pengaruh positif terhadap total kompensasi dan bersifat signifikan. Sehingga $\mathrm{Ha}_{4}$ tidak ditolak. Hasil penelitian Suryana dan Nila (2018) memiliki hasil positif dan signifikan terhadap total kompensasi. Hal ini berdasarkan teori keagenan bahwa kompensasi eksekutif merupakan bentuk solusi dari kontrol pemilik perusahaan terhadap eksekutif perusahaan (agen) untuk menyelaraskan kepentingan keduanya dalam rangka meningkatkan kinerja perusahaan.

\section{KESIMPULAN}

Hasil penelitian menunjukkan bahwa kepemilikan institusional dan komisaris independen memiliki dampak yang signifikan terhadap kinerja perusahaan. Namun, ukuran komite audit tidak berpengaruh pada kinerja perusahaan. Selain itu, kinerja perusahaan tidak memberikan kontribusi yang signifikan terhadap kompensasi eksekutif.

\section{SARAN}

1. Penelitian ini menggunakan variabel kepemilikan institusional, komite audit, komisaris independen dan ROA. penelitian selanjutnya diharapkan dapat menambahkan variabel seperti :firm size, board size, ukuran perusahaan, leverage, resiko bisnisdan dengan menggunakan Tobin's Q.

2. Sampel yang akan menjadi data penelitian selanjutnya dapat memperpanjang periode penelitian agar diperoleh hasil yang lebih akurat.

3. Jumlah perusahaan yang digunakan dalam penelitian ini menggunakan perusahaan manufaktur sebanyak 77 perusahaan, penelitian selanjutnya diharapkan menggunakanseluruh perusahaan yang terdaftar di BEI agar diperoleh hasil yang lebih akurat lagi. 


\section{DAFTAR PUSTAKA}

Bansal, N. dan Anil, K.S. 2016. Audit Committee, Corporate Governance and firm performance: Empirical Evidence From India. International Journal of Economics and Finance, Vol. 8 (3), 103-116.

Bijzak, et al. 2015. Performance-Contingent Executive Compensation and Managerial Behavior. Diunduh dari internet http:// ssrn.com pada tanggal 8Agustus 2019.

Darwis, H. 2009. Corporate Governance Terhadap Kinerja Perusahaan. Jurnal Keuangan dan Perbankan, Vol. 13 No. 3 September 2009, 418-430.

Hamdani. 2016. Good Corporate Governance (Tinjauan Etika dalam Praktik Bisnis. Jakarta: Mitra Wacana Media.

Hidayah, R., Zahid, A., Suryarini, T., Basher, S. R., \& Handoyo, E. (2019). Corporate Performance and Executive Compensation in Indonesia. The Journal of Social

Sciences Research, 634-639.

Ipinnaiye, Olubunmi Alic. 2014. Drivers of firm performance: a holistic and multivariate panel data approach. Small Business Economics. Vol.48. No.4,883-911

Jensen, Michael C. \& Meckling, William H. 1976. Theory of The Firm: Managerial Behaviour, Agency Cost and Ownership Structure. Journal Of Financial Economics. Vol 3, No.4

Theacini, D. A., \& Wisadha, I. G. (2014). Pengaruh Good Corporate Governance, Kualitas Laba dan Ukuran Perusahaan Pada Kinerja Perusahaan. E-Jurnal Akuntansi Universitas Udayana, 733-746.

Peraturan, Otoritas, J. and Keuangan, N. (2015). Tentang Pembentukan dan Pedoman Pelaksanaan Kerja Komite Audit. Available: www.ojk.go.id/regulasi/peraturan ojk/POJK-Nomor55.POJK.04.2015/

Putra, B.P.D. 2015. Pengaruh dewan komisaris, proporsi komisaris independen,terhadap kinerja perusahaan. Jurnal Manajemen Teori dan Terapan, Vol. 8 (2),70-85.

Salvatore, D. (Fifth Edition). Managerial Economics. Singapore: Thomson Learning.

Suharli, M. 2006. Studi Empiris terhadap Faktor-Faktor yang Mempengaruhi Nilai Perusahaan pada Perusahaan Go Public di Bursa Efek Indonesia. JurnalMaksi, Vol.6

Suherman, F. R. and dan Ahmad, G. (2015). Komisaris Independen terhadap Total Kompensasi, Studi pada Perusahaan yang Terdaftar di LQ45 Tahun 2009 - 2012. 516.

Wiranata, Y. A., \& Nugrahanti, Y. W. (2013 ). Pengaruh Struktur Kepemilikan Terhadap Profitabilitas Perusahaan Manufaktur di Indonesia. Jurnal Akuntansi dan Keuangan, $15-26$. 